

\title{
Pharmaceutical Patent Law In-the-Making: Opposition and legal action by states, citizens and generics laboratories in Brazil and India
}

\author{
Maurice Cassier
}

\section{- To cite this version:}

Maurice Cassier. Pharmaceutical Patent Law In-the-Making: Opposition and legal action by states, citizens and generics laboratories in Brazil and India. Making Drugs, Ways of Regulating, 2013. halshs-02165451

\author{
HAL Id: halshs-02165451 \\ https://shs.hal.science/halshs-02165451
}

Submitted on 25 Jun 2019

HAL is a multi-disciplinary open access archive for the deposit and dissemination of scientific research documents, whether they are published or not. The documents may come from teaching and research institutions in France or abroad, or from public or private research centers.
L'archive ouverte pluridisciplinaire HAL, est destinée au dépôt et à la diffusion de documents scientifiques de niveau recherche, publiés ou non, émanant des établissements d'enseignement et de recherche français ou étrangers, des laboratoires publics ou privés. 


\title{
Pharmaceutical Patent Law In-the-Making: Opposition and legal action by states, citizens and generics laboratories in Brazil and India
}

\author{
Maurice Cassier
}

After the first patent laws on inventions were enacted in the late 18th century, parliaments, governments, institutions and medical professions endeavoured to limit or suspend the extension of monopolies on remedies, in the interests of public health. In 1844 the French parliament, against the government's advice, prohibited patents on medicines for a century. In this respect it followed the line of the Académie de Médecine, which at the time was fiercely opposed to monopolies on medicinal remedies. After 1944, when pharmaceutical processes could again be patented in France, the government instituted a "special licence" justified in the name of public health. This measure granted the Ministry of Health the authority to resort to such a licence if it deemed that medicines were not sufficiently accessible in terms of price, quality or quantity (Cassier, 2000). Despite the early internationalization of patent rights, via the Paris Convention of 1883, many other states also excluded medicines from patenting. This was the case for instance in Germany, until 1968, and Japan, until 1975. The developing countries of interest to us here, Brazil and India, likewise opted for the non-patentability of pharmaceutical products, respectively in 1945 and 1970. In 1994 a new phase of globalization of intellectual property was however initiated with WTO trade regulations that extended 20-year patents on medicines to all member countries (May, 2000). Two years later the Brazilian parliament passed a law recognizing pharmaceutical patents, even though the WTO international standard did not come into force until a decade later. India, on the other hand, stalled until March 2005.

In the late 1990s, the globalization of medicine patents triggered an upsurge of actions by governments and civil society calling for the regulation of the scope of these patents. They endeavoured to use every form of flexibility in the WTO agreements and national laws in order to strike a balance between intellectual property and access to new treatments. In response to the new hegemony of 20-year 
medicine patents ${ }^{1}$, a counter movement developed, with the slogan "patients' rights against patent rights" ${ }^{2}$. The initiators and promoters were certain countries of the global South, like Brazil and India, NGOs engaged in campaigns for access to treatment, especially in the context of the Aids epidemic and the arrival of tritherapies from 1996, and public and private laboratories producing generic medicines, who thus defended their possibility to copy new medicines that fell under the 20-year patent law. The emblematic event in this new period of conflict was the Pretoria medicine trial, from 1998 to 2001, in which an international coalition of 39 pharmaceutical laboratories and the national pharmaceutical producers' union sued the South African Ministry of Health and the NGO Treatment Access Campaign (founded in 1998) supporting it. The plaintiffs challenged the validity of two articles of the South African Medicines and Related Substances Control Amendment Act, which granted the Ministry of Health the authority, "in certain circumstances", to decide on compulsory licences and parallel importation of medicines. During the same period, in 1999, the French NGO Médecins Sans Frontières (MSF - Doctors without Borders) launched its campaign for access to treatment. During that period MSF initiated cooperation with the Indian laboratory Cipla, to obtain inexpensive tritherapies. Cipla approached the South African government at the beginning of 2001 with an offer of generic medicines in the event of a compulsory licence. The pharmaceutical industry's Sainte Alliance ("holy alliance") withdrew its complaint, leaving the South African law intact, but negotiated an agreement to ensure that it would not be affected by compulsory licences. This legal tug-of-war was also emblematic of a new activism regarding medical therapies, bringing together states especially their Ministries of Health -, international NGOs and patient organizations, and generics laboratories in the global South (Biehl 2009; Loyola 2009). The Pretoria

\footnotetext{
${ }^{1}$ Cf. the recommendations of the US Academy of Science in a report dated 1997, to extend this hegemony: "America's vital interest in global health: protecting our people, enhancing our economy and advancing our international interest".

2 This was the slogan of the Treatment Access Campaign in 2001 during the Pretoria trial (Cassier 2002; Beigbeder 2004). It sums up the spirit of counter-hegemony fostered by NGOs, activist laboratories such as Cipla in India and Farmanguinhos in Brazil, Health Ministries, and studies on the economy of access to HIV/Aids medicines, for example the two collective volumes published in English by the Agence Nationale de Recherche sur le Sida (ANRS - the French national agency for Aids research) in 2003 and 2008.
} 
trial furthermore marked the globalization of NGOs' struggles over medicine patents (Cassier, 2002).

These struggles through the law (petitioning patent offices, lawsuits) and over the law (public campaigns) have proliferated since the early 2000s, especially in Brazil and India. In Brazil, struggles to obtain compulsory licences have intensified since 2001, under the impulse of the HIVIAids programme, MSF Brazil, Aids patient organizations, and public and private generics manufacturers engaged in reverse engineering of patented ARVs. Legal opposition to patents provided for by Brazilian patent law and Indian law has multiplied since 2006 and led to several refusals of patents on ARVs and on a particularly expensive cancer medicine, Glivec, owned by Novartis. This opposition often brings together NGOs and generics laboratories, to defend the accessibility of medicines and the local production of generics. Major court cases have taken place and have contributed to jurisprudence in this domain. In the Merck laboratories versus FarManguinhos (Brazilian public pharmaceutical laboratory) trial in 2006, the court ruled that a local laboratory had the right to reverse engineer a patented medicine and then to register it as a generic. In the same year, Novartis sued the Indian government for refusing its patent on Glivec, and for an article in the Indian patent law that prohibited the patenting of new formulae for known molecules. The court ruled in 2007 that a state had the right to define the bounds of patentability, in the public interest.

The study of these actions and regulatory measures, and of the special mission to examine pharmaceutical patents that was entrusted to the Brazilian medicine agency in 2001, enables us to reconstruct the process of pharmaceutical patent law in-the-making. We see how legal battles and the intervention of the Brazilian medicines agency in the patent-granting process resulted in stricter patentability criteria and in several patents falling into the public domain. Public campaigns for compulsory licences, and the Brazilian state president's May 2007 decision to approve a compulsory licence on a patented ARV, effectively exploited all the flexibilities in patent law, against all external and internal pressure ${ }^{3}$. These struggles, measures and decisions have defined a new balance of power between the owners of therapeutic inventions and the actors of public health, and between the

\footnotetext{
${ }^{3}$ On the external pressure exerted on Brazil, see Flynn, 2009.
} 
monopolies of the laboratories of the global North and the Brazilian and Indian generics producers' right to copy.

This article considers several measures and actions to regulate medicine patents in Brazil and India. The first section examines the procedure of prior consent by the Brazilian medicine agency, for the granting of pharmaceutical patent rights. The second section analyses the Merck/FarManguinhos trial in which the court authorized reverse engineering on patented molecules. The third section studies a third form of flexibility, that is, the use of compulsory licences to authorize the importing or local production of a patented medicine, Efavirenz, used extensively to combat the Aids epidemic. In the fourth section I describe the legal battles in which NGOs and generics producers in Brazil and India demanded the prohibition of patents on another commonly-used ARV, Tenofovir. The fifth section describes the opposition and the lawsuit over Glivec in India. Finally, the sixth section considers the process of legal acculturation of NGOs in the intellectual property field, and the diffusion of legal counter-expertise through these new actions.

\section{1- Prior consent in Brazil: when the sanitary security agency intervenes in the process of granting pharmaceutical patents (2001-)}

In 2001, as the Brazilian programme for the free and universal distribution of tri-therapies for HIV/Aids was becoming a model for treating the epidemic, Brazilian Minister of Health and development economist José Serra ${ }^{4}$ decided to institute a new procedure for examining and granting pharmaceutical patents. The procedure, which involved the Brazilian national sanitary security agency, ANVISA, in addition to the national industrial property institute, INPI, was incorporated into the 2001 patent law: "The granting of patents on pharmaceutical products or processes shall be dependent on prior consent from the National Sanitary Surveillance Agency ANVISA" (Article 229C). In terms of this article, the sanitary security agency had the power to refuse a patent granted by the INPI. This dual authority was fiercely challenged by the INPI: "When we send out a patent for analysis by ANVISA it is because INPI has already given its approval. So every time they refuse to grant this patent we have different reports" (the President of INPI at a public hearing at the

\footnotetext{
${ }^{4}$ See the article by Andrea de Loyola, 2009.
} 
Chamber of Deputies, 11 November 2009). The coordinator of intellectual property at ANVISA justified his agency's intervention in the patent-granting process in terms of the special status of medicines: "Luiz Lima said that medicines are so important that the entity which is a national authority in public health should be added to the review process" (public hearing at the Chamber of Deputies, 11 November 2009). ANVISA's head of intellectual property at argued that patents could not be granted on the basis of industrial interests only, promoted by the INPI; it also had to take public health interests into account. The agency's involvement in the process of examining patent applications and granting patents was consistent with its mission of controlling the quality, safety, usefulness and accessibility of health products. It had to ensure that pharmaceutical patent rights were not contrary to public health interests and especially the Health Ministry's programmes: "Therefore", he said, "there is a need for a careful review because they are giving a monopoly, and must take into account that this implies a lack of competition and, consequently, the final price of the product to the public and for Health Ministry programmes" (Luis Carlos Lima, ANVISA at a hearing on second-use medicine patents, 2008). The coordinator of intellectual property advocated a conception of property that included its "social function" , and ANVISA was the guarantor of that social function of intellectual property rights on medicines. Leaving it entirely up to the INPI, as certain members of parliament proposed, would undermine the public interest: "If approved", he added, "it could cause a serious drop in the quality of the examination of pharmaceuticals patents, generating worrisome economic and social consequences to society" (Lima 2008). The lawyers of patient organizations involved in discussions on intellectual property in Brazil saw prior consent as a measure to protect patients' interests: "Prior consent by ANVISA is not, therefore, simple interference in the patent-granting procedure. It is a measure to protect patients, by preventing medicine patents from being awarded when they are undeserved" (Chaves, Viera \& Reis 2008). The NGOs involved in battles over IP rights supported ANVISA's coordination of intellectual property rights.

\footnotetext{
5 "Regulação sanitária, propriedade intelectual e política industrial", Luis Carlos Lima, COOPI, Anvisa, 19-21 May 2008). See also the article by Brazilian jurist Maristela Basso, 2006, which shows that the "social function of property" is enshrined in the Brazilian constitution. Basso argues that this is the legal basis for the procedure of prior consent by ANVISA on pharmaceutical patents.
} 
The implementation of prior consent by ANVISA required the creation within the agency of a group of patent examiners. This unit, called the Coordination of Intellectual Property, was located in Rio de Janeiro very close to the INPI, to facilitate interaction between the two. In 2001, ANVISA recruited 16 professionals (chemists, pharmacists, biologists) who had received training in intellectual property. Four teams were created, each supervised by four examiners who had worked at the INPI for two years. The first patents examined were each discussed and evaluated by a team ${ }^{6}$. Today, after that initial learning period, the examiners carry out an individual examination which is then submitted to the Technical Support Group, consisting of four chemical engineers, a doctor and a lawyer, and which supervises and discusses each file. The COOPI thus brings together patent examiners specialized in the field of pharmaceutical chemistry and biomedicine, and lawyers who have trained their colleagues in patent law. During the period from 2001 to 2009, when over 1,000 files were examined, this combination of scientific and legal competencies and teamwork created a learning dynamic. The legal expertise and examination practices of ANVISA's IP department are very similar to those of the INPI examiners. It even seems that the ANVISA examiners have more time to examine each file than that allocated to their colleagues at the INPI ${ }^{7}$. Moreover, the ANVISA examiners study a patent application after the INPI examiners have done so, and have access to their examination reports. Since 2001, the ANVISA team of examiners has gradually been consolidated and has developed a corpus of rules and knowledge in the process of examining over 1,000 patent applications. It can therefore be said that ANVISA now hosts a sort of counter-expertise to that of the INPI as regards the patentability of medicines. It is precisely this counter-expertise that was criticized in the Chamber of Deputies in November 2009 when the INPI president challenged the duplication and confusion of roles between the two agencies. He also criticized the quality of ANVISA's expertise: "It's a small group, yet it is much broader and better prepared than the group of only 18 researchers that Anvisa has" (President of INPI, November 2009).

The reality of this counter-expertise is evidenced in the existence of a set of rules and interpretations which partially differ from those of the INPI. The ANVISA

\footnotetext{
${ }^{6} \mathrm{Cf}$. the data collected by E. Guimaraes, 2008, Phd thesis at the UERJ.

7 Visit to the COOPI at ANVISA, Rio de Janeiro, March 2006.
} 
COOPI evaluates patent applications on the basis of set patentability criteria: novelty, inventiveness, and industrial application. It emphasizes the technical and legal nature of its examination work, thus denying any "ideological" basis, of which it is sometimes accused $^{8}$. By taking Brazilian patent law and the WTO TRIPS agreements as its references, it anchors its work in national and international law. At the same time, the COOPI also develops its own corpus of interpretations and guidelines that differs from that of the INPI in several respects. The most noteworthy disagreements concern the patentability of the second therapeutic use of a known molecule and of polymorphic molecules. Whereas ANVISA refuses these two types of patent, INPI accepts them. ANVISA considers that patents on a second therapeutic application of a known molecule are "detrimental to public health and to the country's scientific and technological development, and could impede access to medicines" (Guimaraes 2008). The COOPI's argument is grounded on the principle of accessibility of medicines, and on the hypothesis that the granting of new patents on a known molecule would hinder research for the development of new applications. It contends that the preservation of the public domain is conducive to the free development of investigations. In 2008 the inter-ministerial group on intellectual property (GTPI) followed ANVISA's guidelines and decided to limit the granting of patents on the second therapeutic use and polymorphs. In May 2009 the parliamentary commission on social security also passed a bill prohibiting the patentability of the second use and polymorphs ${ }^{9}$. The controversy spread to the public sphere: a pharmacists' union, the FENAFAR, endorsed ANVISA's guidelines and demonstrated against patents on the second therapeutic application.

These differences of interpretation concerning the rules of patentability, especially the fact that ANVISA adopts higher standards of patentability in order to safeguard the public domain, explain many refusals of patents initially approved by the INPI. The statistics produced by the COOPI show a $5 \%$ refusal rate on patents approved by the INPI. ANVISA has emphasized the technical nature of these refusals: "simply for strictly legal reasons such as the lack of novelty or inventive activity". The INPI has retaliated by consistently refusing to publish these decisions,

\footnotetext{
${ }^{8}$ Public hearing, Chamber of Deputies, November 2009.

9 "The Committee on Social Security and the Family approved on Wednesday (27), a bill prohibiting the granting of patents on therapeutic indications for pharmaceutical products, and on polymorphic substances (Chamber of Deputies, 29 May 2009).
} 
so that the medicines in question have never been formally put into the public domain (Chaves, Viera, Reis, 2008).

The intervention of the national medicine agency in the patent domain has generated considerable opposition and controversy: "The INPI argues that the role of Anvisa should be limited, as set out in Bill 3709/08, introduced by Deputy Rafael Guerra (PSDB-MG). Anvisa, on the other hand, has criticized the proposal, arguing that it does not serve the public interest" (ANVISA and INPI disagree on Bill that changes Patent Law, 27 November 2009). Pharmaceutical laboratories affected by ANVISA's refusal of their patents have sued the agency on the basis of what they deem to be the illegitimate intervention of the COOPI. For instance, Aventis, to which ANVISA refused to grant a patent on Taxotere, accused the agency of overstepping its prerogatives which, according to the pharmaceutical firm, were strictly limited to sanitary affairs (Federal Court of Rio, 15 July 2008). This was also the position of private consultants in industrial property, who maintained that ANVISA's prior consent should apply only to sanitary criteria and not to patentability: "We can see that with prior consent, ANVISA cannot reassess the requirements of patentability itself. ANVISA should be limited to its skills and evaluate the chances that new medicines or new uses for known medicines, could - even if only potentially - cause harm to the population's health" (Roner, Guerra, Fabris, 16 October 2009). The INPI, Aventis and certain legal firms have thus confined ANVISA's and the Ministry of Health's province to sanitary issues, whereas in their opinion industrial property is the prerogative of the INPI alone. ANVISA's COOPI however defends a completely different point of view that justifies its "social function" and its duty to strike a balance between industrial and public health interests. The struggle has been intensified by the fact that ANVISA has developed real expertise on medicine patents, which has proved to be an alternative to that of the INPI in certain respects. Pharmacists' unions, Aids patient organizations, networks of NGOs working on intellectual property (the Working Group on Intellectual Property - GTPI- of the REBRIP - the Brazilian network for the Integration of Peoples), the parliamentary commission on social security, and the deputies of the $\mathrm{PT}^{10}$ all support the COOPI's action.

10 The Labour Party, from which President Lula came. 


\section{2- Obtaining the right to do RE on a patented medicine, in the name of the public interest: the Merck/FM trial (2004-2006)}

In 1997 the Brazilian Ministry of Health launched a programme for the reverse engineering of ARVs, with a view to developing local production of generic medicines to supply its free and universal distribution of tri-therapies (Cassier \& Correa 2003). The copying of the first ARVs was licit as Brazil had excluded pharmaceutical products from patenting from 1945. Paradoxically, when the Ministry of Health launched its copying programme, parliament adopted the new WTO standard instituting 20-year pharmaceutical patents. The evolution of tri-therapies led the Ministry increasingly to use medicines that, under the new standard, were patented and therefore not legally reproducible. From the early 2000s, the Ministry of Health threatened patent-owning companies with compulsory licences that would authorize the production of molecules patented by third parties in Brazil, without the owners' authorization. To make the threat credible, the Ministry of Health encouraged the federal laboratory FarManguinhos to develop the reverse engineering of patented molecules. One of the most frequently used molecules in tri-therapies in Brazil was Efavirenz, patented by Merck. In 2001 Merck wrote to FarManguinhos, asking it to cease its work on a molecule that it, Merck, owned. The federal laboratory replied that its research concerned the raw material of a patented medicine and was licit in so far as it was not for commercial purposes. This research on reverse engineering was used by the Ministry of Health to secure discount prices on a medicine that absorbed $10 \%$ of its Aids programme budget. In case of deadlock, the Ministry could opt for a compulsory licence to produce Efavirenz locally: "If they agree to a lower price we will not launch local production, but if they don't, then we're ready" ( $E$. Pinheiro, Director of FarManguinhos, March 2001). Merck eventually agreed to a discount price on Efavirenz and the government withdrew its threat of a compulsory licence. Reverse engineering work continued in 2002, primarily to produce a standard of the molecule under an R\&D programme funded by the sanitary security agency.

In parallel with the reverse-engineering work, the federal laboratory engaged in negotiations with Merck to obtain a voluntary licence to produce Efavirenz locally ${ }^{11}$.

\footnotetext{
${ }^{11}$ Inteview with the director of FarManguinhos, Nubia Boechat, April 2004.
} 
In March 2004 Merck decided to freeze negotiations after several Brazilian laboratories, both public (Lafepe) and private (Cristalia, Labogen and Globe), registered several Efavirenz generics with ANVISA. In September 2004, FarManguinhos put out an international call for tenders for $200 \mathrm{~kg}$ of raw material for Efavirenz, with a view to developing the technology and producing the batches required by ANVISA to register the generic. The objective was twofold: to pressurize Merck into resuming negotiations on a voluntary licence; and to acquire the technology so that it could register the generic and prepare a compulsory licence, if necessary. Merck immediately demanded the withdrawal of the call for tenders, claiming that it was the only firm authorized to produce and commercialize Efavirenz. It denounced the call as "an illegal and inconceivable compulsory licence on a patented product"12. FarManguinhos then turned to Merck to supply it with the $200 \mathrm{~kg}$ of raw material for the purposes of "research and technological development" (letter dated 29 September 2004). The call for tenders was suspended and negotiations on a voluntary licence were resumed. A Merck team visited the FarManguinhos laboratories in October 2004, but neither the purchase of the raw material nor the voluntary licence materialized. FarManguinhos refused Merck's price offer: whereas its reference was generics prices, Merck's was the patented raw material. Moreover, Merck claimed that it was unable to supply the requested raw material: "...given the increasing number of patients and the consequent increase in global demand for Stocrin" (letter dated 17 February 2005). FarManguinhos then addressed its call for tenders for the active principle of Efavirenz to the Indian generics producer Aurobindo. On 18 February 2005, Merck laid charges against FarManguinhos and demanded the cancellation of this call for tenders ${ }^{13}$ on the following grounds: the fact that FarManguinhos had broken off negotiations, whereas it (Merck) had shown its good will to cooperate with the Aids programme; that the Indian generics laboratory chosen had not presented all the technical guarantees required in such a sophisticated medicine; that a patented molecule could not be open to competition in a call for tenders; that the transactions of the call for tenders were of a commercial nature even though FarManguinhos was a research institution; and, finally, that the

\footnotetext{
${ }^{12}$ Archives of the trial, p. 39.

${ }^{13}$ In December 2004 the Brazilian laboratory Cristalia also demanded the cancellation of the call for tenders on the grounds that the Indian generics producer had not supplied all the technical specifications. Cristalia withdrew its complaint in early January 2005.
} 
aim of this call for tenders was not R\&D but the commercialization of a patented product.

FarManguihnos based its position on two exemptions in Brazilian patent law and in the WTO TRIPS agreements: an exemption on research to acquire knowledge and technology; and the Bolar exemption that authorized research on a patented medicine with a view to registering its generic. The federal laboratory justified the acquisition of the technology and the registration of the generic on the grounds of the urgency of making treatment available to patients: "those who are suffering from the unjustified delays in research on HIV are the people carrying the virus, who have once again been put second after private financial interests".

Initially the Rio de Janeiro Federal Court ruled in favour of Merck and ordered the suspension of the imports. It justified this decision on the grounds that reverse engineering with a view to registering generic medicines was a long-term process until the expiry of the patent in 2012 - and did not correspond to an emergency. FarManguinhos appealed however, and the Federal Court's ruling was quashed in August $2005^{14}$. On appeal, the court reversed the decision and ruled in favour of FarManguinhos, in the interests of public health and the necessity to reverse engineer the molecule: "the delay in developing the above-mentioned research will lead to delays in acquisition of the technology and the production of generic medicines"; "... the delay or banning of production will be detrimental to public health due to the lack of generic medicines on the market"15. The new ruling was thus made on the grounds of public health interests and the urgency to acquire the appropriate technology. The priority was no longer the duration of patent rights but the development of generic medicines in the interests of the population's health. This order of priority was clarified in the 6 October 2005 ruling: "In view of the conflict of interests in this case, we have to emphasize that the economic interests of Merck, the holder of the patent on the medicine Efavirenz, does not take precedence over the joint interests of protecting both the economic order and public health" (Federal Court, 6 October 2005). The protection of the economic order refers here to the interests of the public economy of pharmaceutical R\&D undertaken at Fiocruz, which would suffer from any delay in acquiring the pharmaceutical technology. This

\footnotetext{
1417 August 2005 ruling, Rio de Janeiro Regional Federal Court.

${ }^{15} 6$ October 2005 ruling, Regional Federal Court of the $2^{\text {nd }}$ Region.
} 
decision embedded the Bolar exemption in Brazilian law. In December 2006, when the Federal Regional Court confirmed the ruling, the Director General of FarManguihnos encouraged the government to opt for a compulsory licence on Efavirenz. He claimed that his laboratory was able to produce the medicine at half the cost of the price proposed by Merck. The lawsuit filed by Merck in February 2005 had however brought research on Efavirenz to a standstill for two years ${ }^{16}$.

\section{3- Policy of universal access to HIVIAids medicines (1996) and decision on compulsory licences in Brazil (May 2007)}

The compulsory licence is the most emblematic and controversial measure in patent law. It consists not only in "quashing the patent", as the Brazilians say, but also in revoking the exclusivity of appropriation. It is, in a sense, a form of public expropriation, except that the owner loses only the monopoly and not the patent itself. The 1994 WTO agreements on intellectual property do not cover the compulsory licence but do contain an article that defines and codifies it as follows: the authorization to use a patent without the owner's authorization, especially for reasons pertaining to public health, national emergency, and non-commercial use by the government (Article 31). Debate on the compulsory licence revolves around the fact that it challenges the idea underlying the whole patent system: the monopoly. Yet many countries have included compulsory licences for public health reasons in their patent laws. The UK and Canada did so in the early $20^{\text {th }}$ century, and France in the 1950s. Economist F. Scherer has studied its use in the USA for pharmaceutical inventions, especially in the 1960s and '70s (Scherer, 2000). Activists for access to medicines point out that in September 2001, in the context of a biological anthrax threat, the US Secretary of State for Health threatened Bayer with a compulsory licence if the firm did not lower the price of its antiobiotic.

In the past the UK, the US, Canada and Germany applied compulsory licences to undo monopolies that seemed detrimental to public health interests, or for the purpose of systematically producing generic medicines, as in Canada in the 1970s and '80s. The difference today, of particular interest to us here, is the fact that it is now countries of the global South that have decided on a series of compulsory

\footnotetext{
${ }^{16}$ Interview with the deputy director of FarManguinhos, George Costa, in May 2009.
} 
licences to import or locally produce medicines made accessible to their populations. Since the early 2000s there has been a real movement in this respect in South-East Asia (Indonesia, Malaysia, Thailand), Africa (Zimbabwe, Mozambique, Ghana), and Latin America (Brazil, Ecuador). This geopolitics of compulsory licences seems to be a direct response to the globalization of pharmaceutical patents in countries where medicines were excluded from patenting before the WTO agreements. It is also a movement related to the emergence of new demands in terms of rights to treatment or simply to life, especially in the context of the Aids epidemic. The vast majority of compulsory licences concern the importation or local production of ARVs. These compulsory licences are based on the existence of a pharmaceutical industry of generic medicines that has developed over the past three decades in India (Lanjouwe 1997; Sahu 1998; Scherer and Watal 2001), Brazil (Cohen 2001; Cassier and Correa 2003) and Thailand, where they contribute in turn to developing a SouthSouth generics market. Brazil initially imported Efavirenz from India, under a compulsory licence, before producing it locally.

In Brazil the stakes involved in a compulsory licence decision were high. First, the policy of free and universal access to HIV/Aids treatment, including the most recent tri-therapies, generated tensions around the new patent law that came into force in 1997. Whereas the local production of a generic version of the first ARVs had limited the Health Ministry's expenditures, by the mid-2000s the purchase of new patented ARVs from proprietary laboratories was absorbing four-fifths of its budget. Second, this extension of the patented pharmacopoeia reduced the possibilities for copying and producing generic medicines to virtually nil. The technological learning dynamic of Brazilian laboratories for duplicating such sophisticated medicines as ARVs was thus being ruined by increasingly broad property rights. Consequently, the use of compulsory licences seemed to be the most viable solution both to maintain the policy of universal access to HIV/Aids treatment, and to reopen the space for local laboratories to carry on copying. The compulsory licence decision therefore seemed to be justified and legitimate on two counts: the Brazilian government's health policy regarding the Aids epidemic, which was held up as a model of public health management (Teixeira et al. 2003); and the development of local pharmaceutical production to supply the domestic demand.

The first struggles for a compulsory licence in Brazil erupted in the summer of 2001, in a case involving Roche, and recurred in 2003 and 2005. The Ministry of 
Health used them as a threat in its negotiations with the proprietary laboratories, to obtain price cuts on patented ARVs. While the clashes of 2001 and 2003 were saluted as victories when the multinational firms agreed to substantially lower their prices, the battle with Abott in 2005, over Kaletra, was seen as a defeat. In this case the Ministry of Health had opted for a commercial agreement rather than settling the matter in court. The battle was waged by 50 national and international NGOs, along with the Director of the HIV/Aids programme, Pedro Chequer, who had campaigned for a compulsory licence: "Chequer used his speaking engagements at the conference to emphasize his opinion that the Brazilian government should move forward with compulsory licensing to ensure the best care for its citizens" (lavi Report, 9 July 2005). The NGOs criticized the "paper tiger". Those Brazilian generics laboratories that had embarked on the reverse engineering of patented molecules believed that the commercial pressure of the United States was too great and that the threat of a compulsory licence was nothing but "bravado" (Director of R\&D at Cristalia, 2004)17. Yet in May 2007 the President of Brazil signed a decree on a compulsory licence to import or locally produce Efavirenz in the public interest and for non-commercial use. How can we explain a decision for which there was such a strong demand, especially by the Brazilian Ministry of Health and NGOs, and the same time such strong opposition, primarily from the authorities of the United States and the International Federation of Pharmaceutical Industries and Associations? ${ }^{18}$

A decision of this nature assumed that the public health norm would take precedence over the industrial property norm. That was in any case how the Brazilian President and the heads of the Health Ministry's Aids programme justified the decree on a compulsory licence. It also corresponded to the demands of the campaign launched by national and international NGOs. At the beginning of 2003, MSF Brazil acted as a precursor and federator when it urged the Brazilian government to take out a compulsory licence. In April 2003, Michel Lostrowska, MSF Brazil's head of the campaign for access to treatment, organized an international forum in Rio de Janeiro to prepare this decision. The meeting was attended by representatives of NGOs such as Oxfam and Consumer Project on Technology ${ }^{19}$, the FarManguinhos Institute (that was producing ARVs for the Aids programme), the Oswaldo Cruz Foundation, the

\footnotetext{
17 Interview held in April 2004 in Itapira.

${ }^{18}$ See for example the file on the Brazilian compulsory licence, put together by the CPTech.

19 James Love participated in this seminar in Rio de Janeiro.
} 
INPI, the Chemicals Industry Union of Brazil, economists from the Federal University of Rio, the heads of Brazil's Aids programme, and lawyers specialized in intellectual property ${ }^{20}$. This forum was emblematic of Brazil's new pharmaceutical governance involving generics laboratories, scientists, NGOs, and jurists. It encompassed several fields of expertise, notably law, science, technology, and public health, to produce an argument in favour of compulsory licences. In July 2005, 50 national and international NGOs published a joint statement in favour of a compulsory licence on Abott's Kaletra: "We, the undersigned Brazilian and international Civil Society Organizations and Networks, urge the Brazilian government immediately to authorize a compulsory license on Lopinavir/Ritonavir and begin local generic production of this important AIDS medicine without delay. This step would be historic, not only for Brazil but for the entire developing world" (Joint Civil Society Statement on Brazilian Compulsory Licensing Dispute, July, 2005). The campaign for a compulsory licence provided a framework for the integration of Brazilian NGOs, spread across the country, and interaction with international NGOs based both in the global North (e.g. Aide and Act Up Paris, and Essential Action in New York) and in the global South (among others, Zimbabwe AIDS Network and Coordinadora Peruana). In August 2005 the National Health Council of Brazil recommended a compulsory licence on three ARVs: Kaletra, Efavirenz and Tenofovir. It justified this in terms of: the policy of universal access to ARVs, which was in keeping with the Brazilian constitution; the beneficial impact of this free distribution of medicines on the health of infected persons; the conformity of a compulsory licence with Brazil's patent law; and the WTO agreements on intellectual property. The National Health Council recommended the local production of these medicines, an increase of research funding to public pharmaceutical laboratories, and a national debate initiated by the Ministry of Health with a view to amending Brazil's patent law. The idea of a compulsory licence became an overriding concern at the Ministry, which surrounded itself with legal expertise on patents ${ }^{21}$. The fate of the compulsory licence was playing out at the same time on the legal scene, in the trial between Merck and the FarManguinhos Institute.

\footnotetext{
${ }^{20}$ I was also invited to this forum as an expert, financed by the French national agency for Aids research (Agence Française de Recherche sur le Sida - ANRS).

${ }^{21}$ For example, the report by a patent specialist at the INPI and the FarManguinhos Institute, to prepare a compulsory licence in 2004.
} 
As the public health norm started to prevail in the public debate among health experts both at home (National Council of Health) and abroad (the WHO Drug Action Program Essential Drugs, headed by German Velasquez), and among experts on patent law mobilized by Brazil's Aids programme, both nationally (FarManguinhos IP unit) and internationally ${ }^{22}$, the battle was being fought on the technological front in the R\&D laboratories of Brazilian generics producers. The compulsory licence was not only the product of legal and political work in the public health domain; it was also the fruit of investments in the research of public and private laboratories, to acquire the corresponding technologies and "to be ready" to produce locally. Researchers at the FarManguinhos federal laboratory were asked by the Ministry of Health to prepare the reverse engineering of medicines likely to be placed under a compulsory licence. In 2003 the FarManguinhos chemists went to India and China to visit generics laboratories, acquire information on the relevant molecules, and negotiate the acquisition of raw material ${ }^{23}$. Private-sector laboratories were likewise encouraged to develop synthesis technologies with a view to producing active principles in Brazil. The acquisition of know-how served as a credible threat for the government to wield: "once the national producers have developed reverse engineering, they can talk to multinationals from a strong position, 'if you don't supply us, we have alternatives. We have the knowledge, the know-how' " (Director of R\&D at Cristalia, April 2004). In 2004 the private-sector firms complained about the government's backtracking and it's inability to recoup it's research investments: "the problem with the government, this is the second time that they've said they want to quash the patents. And what happened? They ask us to develop them. I told the government at the beginning of this process: we're going to spend a lot of money to develop the synthesis. We've bought the raw materials, done the research and nothing's happened" (Director of Labogen, Campinas). Having know-how was critical in the process of deciding on a compulsory licence ${ }^{24}$. As the government was unsure about the technical capacities of Brazilian generics laboratories to produce patented ARVs industrially, in 2006 one of the main Aids patient organizations, ABIA, a partner of MSF, financed an

\footnotetext{
${ }^{22}$ The Joint Civil Society Statement on Brazilian Compulsory License Dispute of 2005 was signed by an Associate Professor of Law from West Virginia University, USA.

${ }^{23}$ Interviews held at FarManguinhos in April 2004 with the heads of the mission in India and China.

${ }^{24}$ Consulting report for the Ministry of Health, 2004.
} 
international study on the subject by two chemists ${ }^{25}$. The favourable conclusions of this published study were decisive in the May 2007 decision to finally opt for a compulsory licence.

The compulsory licence decision in a country as strategic as Brazil regarding medicines - considering its local production and the size of its market -, was based on a huge effort to produce knowledge and to shift norms. Technology, public health and law were closely interlinked in the arguments of the Ministry of Health, the NGOs, and the generics laboratories. Campaigns for a compulsory licence in the years from 2001 to 2007 provided the framework for new coalitions between NGOs and the Aids programme, and between the Ministry of Health and private firms. The May 2007 decision in favour of a compulsory license spawned the emergence today of a new organization of industry, with a pharmaceutical consortium consisting of two public and three private laboratories, formed to produce Efavirenz locally. Thus, battles for the compulsory licence contributed to reconfiguring Brazil's health policy and its pharmaceutical economy.

\section{4- Opposition to patents on Tenofovir in Brazil and India: the engagement of NGOs and generics laboratories}

Legal opposition to patents enables third parties - citizens, NGOs, Ministries, firms - to petition the patent office for the refusal or cancellation of a patent. It is a regulatory procedure embedded in patent law, and which takes place within the industrial property institutions. In Brazil the country's patent law authorizes a pregrant opposition procedure, while a patent application is being examined, whereas in India both pre-grant and post-grant opposition is recognized. Generally, opposition procedures are used extensively by firms in an attempt to limit their rivals' patent claims. In the field of health, the fact that the procedure is open to third parties enables a far wider range of actors to challenge a patent ${ }^{26}$. In Europe, civil society

\footnotetext{
${ }^{25}$ Antunes O. \& Fortunak JM, 2006, "ARV Production in Brazil: an Evaluation", report for the Brazilian Interdisciplinary Aids Association (ABIA) and MSF Brazil, 8 pages.

${ }^{26}$ Cassier M. \& Stoppa Lyonnet D, "L'opposition contre les brevets de Myriad Genetics et leur révocation totale ou partielle en Europe" ("Opposition to Myriad Genetics patents and their total or partial revocation in Europe: early conclusions"), Médecins/Sciences, $n^{\circ}$ 6-7, vol 21, June-July 2005, p
} 
organizations, patient organizations, scientific societies, medical institutions, political parties, and Ministries of Health all challenge patents. The same applies to Brazil and India, where the number of oppositions to medicine patents has multiplied since 2006. These procedures afford a framework for the structuring of civil society in the field of health and play an important role in regulating intellectual property. Several major patents have been refused in this way in Brazil and India since 2006, thus contributing to expanding the public domain and the space in which generic medicines can be produced. The first successful opposition, which has served as jurisprudence for other oppositions in India, concerned an extremely expensive cancer medicine Glivec, owned by Novartis. Much like the campaigns for compulsory licences, the oppositions mobilized patient organizations demanding access to treatment, as well as generics laboratories defending the opening of their market in the face of multinationals' patents. In this section I analyse the oppositions filed both in India and in Brazil in May 2006 and June 2008 against the US firm Gilead's patents on Tenofovir, an antiretroviral that is one of the WHO's recommended medicines and is distributed to over 30,000 patients in Brazil. These oppositions were aimed at: i) safeguarding the local production of generics in India, where Cipla had been commercializing a Tenofovir generic since 2005; ii) authorizing the establishment of a local production of generic Tenofovoir in Brazil; and iii) allowing for the acquisition of Indian generics by the Brazilian Aids programme, in which case Gilead's patent would have to be refused in both countries.

In 2006 the FarManguinhos Institute, which produced $40 \%$ of Brazilian ARV generics, filed two acts of opposition to two patents on ARVs: Abbott's Kaletra, and Gilead's Tenofovir. These were the first oppositions to medicine patents filed in Brazil. The argument for the acts of opposition was drawn up by Wanise Barroso, the FarManguinhos federal laboratory's intellectual property expert. Barrosso is a chemist who worked for 20 years as a patent examiner at Brazil's INPI, before being recruited in the early 2000s to form a technology watch unit. In her PhD she focused on the creation of a system of integrated databases for patents, registered medicines, and scientific publications. Wanise Barroso and the FarManguinhos 
Institute were therefore fully equipped to study patent applications, either for the purpose of providing references for the chemists doing reverse engineering, or to oppose patent applications at the INPI. Barroso describes herself as an expert in industrial property who works for public health ${ }^{27}$. She uses her knowledge to provide counter-expertise to that of the proprietary laboratories and the INPI examiners in Brazil, whose job she is thoroughly familiar with. The opposition reports that she has drawn up discuss the patentability criteria applied by the Patent Office on the basis of highly technical arguments, to analyse the molecules to which the patent claim applies. The opposition report that she drew up against Gilead's patents on Tenofovir showed that the molecule to which the US firm was laying claim had been in the public domain for a long time, and that it could not satisfy the criterion of inventive activity. Her opposition was thus based on classical patentability criteria applied by the Patent Office ${ }^{28}$. At the same time, this opposition had the more far-reaching objective of defining stricter patentability criteria, so that patents could not be granted on minor alterations to known molecules. The approach was comparable to the one used by ANVISA's IP unit, that is, to defend the public domain by refusing futile patents or the phenomenon of ever-greening. By filing this act of opposition, the federal laboratory was fulfilling its role as a watchdog with regard to medicine patents, and thus protecting Brazil's space for free copying and generic medicine production. Wanise Barroso thinks that the actors of health in Brazil - laboratories, NGOs, and Health Ministry - should use the opposition procedure as a weapon to defend the local production of generics and accessibility to treatment. She has set up a technology information system to monitor the filing of medicine patents, which can be used to support the policy of free distribution of treatment for carriers of HIVIAids ${ }^{29}$. Wanise Barroso's technical argument circulated among Brazilian NGOs working with Aids and even reached Indian NGOs via MSF, which acted as an intermediary ${ }^{30}$. This circulation between FarManguinhos and MSF was the fruit of

\footnotetext{
${ }^{27}$ Wanise Barroso's talk at a Brazil-India seminar in November 2008 in Rio was titled: "Opposition to pharmaceutical patents: arguments in favour of public health".

${ }^{28}$ Opposition report addressed to the Director of the INPI, Brazil, on 6 December 2005.

29 "Relatorio sobre o medicamento Tenofovir", Wanise Barroso, 2006.

${ }^{30}$ Information supplied by Wanise Barroso on 7 June 2006. The author of this article worked with Wanise Barroso on a collaborative research project between the French CNRS and the Brazilian
} 
multiple exchanges of information and even research partnerships between the two ${ }^{31}$.

The second opposition was filed against Gilead's patent, by a consortium of six NGOs active in the field of Aids, intellectual property, and the defence of the right to life ${ }^{32}$. It was emblematic of the expansion of the scope of patient organizations' intervention in the field of intellectual property, and of arguments that closely interlinked the interests of public health with technical considerations on the patentability of medicines. The NGOs' opposition report was drawn up by lawyers employed by them, who combined the technical arguments provided by FarManguinhos with a legal argument on the Brazilian constitution, the country's public health laws, and laws on the participation of third parties in administrative processes. These lawyers and the IP experts at FarManguinhos pooled their complementary expertise: "FarManguinhos wrote the technical argument, ABIA wrote the legal one" (Wanise Barroso, November 2008).

Initially the legal argument put forward by the patient organizations aimed to justify their participation in the process of patent examination, on the grounds of patent law - which afforded the possibility of intervention by the "interested parties" , and of the federal constitution of 1988 - which guaranteed the right to defence for "interested third parties". The NGOs' lawyers showed that the HIVIAids patient organizations which were "highly active in the field of access to medicines" were clearly "interested third parties" as regards the patent in question, on a medicine used to treat Aids. This opposition was written in highly sophisticated legal terms, so that the organizations' legal expertise would be taken seriously and they would be included in the administrative patent-filing process. It was important for the opponents of the patent to stick to both the terms and the spirit of the law. Once the patient organizations had shown that they did indeed fit the legal category of "interested third parties" and could therefore participate in the patent examination

Oswaldo Cruz Foundation, from 2005 to 2007, to study the implementation of these oppositions. The social sciences thus contributed to structuring of the intellectual property field.

31 Interviews with Michel Lostrowska of MSF Brazil, and with Eloan Pinheiro, Director of FarManguinhos from 2002 to 2004.

32 The six organizations that opposed this patent were large HIV/Aids patient organizations in Rio, Sao Paulo, and in the state of Rio Grande do Sul (ABIA, Conectas Direitos Humanos, Gurpo Pela Vidda, Gapa, Gapa Rio Grande do Sud, Gestos). Opposition report from ABIA, 2006. 
process, they endeavoured to show the contradiction between the policy of universal access to treatment for Aids and the granting of a patent on a medicine like Tenofovir that was used so extensively in tritherapies.The argument highlighted Tenofovir's status as an "essential medicine", to challenge the patent's monopoly. The "essential medicine" category encompasses both pharmacological criteria of sanitary security and therapeutic efficiency, and criteria of accessibility of the medicines selected, that is, cost and public health criteria. As Tenofovir had been added to the list of essential medicines in Brazil (the RENAME), its availability had to be guaranteed by the state, in keeping with the Constitution of 1998 in which the universal right to health was enshrined. The opposition then put forward technical arguments from patent law to challenge the patent on Tenofovir, primarily the absence of novelty and inventive activity.

In fact, opposition to the patent was based on several arguments: the democratic reform of the state - the right for third parties to oppose an administrative process -; the right to health, guaranteed by the state; therapeutic utility; the cost and accessibility of medicines; and the criteria for defining a valid invention. The NGOs stressed that medicine patents had to come to terms with the public and general interest. Considering the absence of novelty, and the fact that it ran counter to the public interest, the Tenofovir patent could not be approved. This was basically the conclusion of the Brazilian NGOs' act of opposition.

Oppositions to the Tenofovir patent were simultaneously filed in India, in May 2006, by a coalition of two HIV/Aids patient organizations and the generics producer Cipla which had started to produce Tenofovir in 2005. The NGOs emphasized patients' rights against patent rights: "For many of us living with HIVIAIDS, newer medicines like Tenofovir offer new hope of continuing treatment. With patents interfering with our lives, we have no choice but to oppose them" (the Delhi Network of Positive People, Third World Network, 23 May 2006). They sought the advice of an association of lawyers, the Alternative Law Forum, to draw up their acts of opposition (two oppositions were filed against two pharmaceutical forms of Tenofovir). The Alternative Law Forum was defined as follows: "ALF was started in March, 2000, by a collective of lawyers with the belief that there was a need for an alternative practice of law. We recognize that a practice of law is inherently political. We are committed to a practice of law which will respond to issues of social and economic injustice". It focused on open source licences and "the commons". From this point of view, these 
lawyers' position was fairly close to that of the lawyers of patient organizations in Brazil, except that the former had founded an independent organization. The opposition reports that they drew up were highly technical and precise (25-30 pages), and followed the same order of examination of patentability criteria as a patent examiner would $\mathrm{do}^{33}$. The preamble of the oppositions justified the patient organizations' action in terms of both the impact that the patents would have on the accessibility of treatment for patients, and gravity of the HIV/Aids epidemic: "This reality creates a difficult situation between the patent system and the matter of life and death". The argument was similar to the one put forward by the Brazilian oppositions: in this context of tension between patents and public health, it was important to grant patents for real innovations only and not for minor alterations to known substances. Here the lawyers could mobilize a highly controversial article in Indian patent law, Article 3d which stipulates that "a mere discovery of a new form of a known substance which does not result in the enhancement of the known efficacy of that substance" is not a patentable invention. They then showed that, even though it presented a gain in bioavailability compared to a preceding form, the new pharmaceutical form concerned by the patent application did not allow for better therapeutic efficacy. The Indian lawyers were able to refer to a recent case concerning the opposition filed by a patient organization against Novartis' patent on Glivec, which the Patent Office had subsequently refused (25 January 2006). Those opposed to patents on Tenofovir pointed out that this case afforded the Patent Office with a new opportunity to make the law and to set the patentability standards of medicines: "The opponents contend that this patent office has the ability to set the standard of patentability so as not grant to such obvious patenting for the benefit not only of public health but also genuine inventions" (Opposition Report I-MAK, p.14). Oppositions made the law and in so doing were able to organize the medicine market: if Indian patents on Tenofovir were refused, the copying and generics markets would be free and the price of medicines would be reduced considerably (the price of the generic Tenofovir produced by Cipla was ten times lower than that of the patented medicine). In May 2006, lawyers and patient organizations organized a demonstration outside the Indian houses of parliament as they filed their opposition.

\footnotetext{
${ }^{33}$ The opposition reports are available on the website of the legal NGO I-MAK, which has taken over these two files since then.
} 
Chanting "We want Tenofovir!" and wearing t-shirts blazoned with the words "HIV positive", the New Delhi protesters drew stares from passers-by. "It's a matter of life and death", said Loon Gangte, president of the Delhi Network of Positive People. "At any moment l'll be developing resistance to my existing treatment and will be needing the next line of treatment in the form of Tenofovir" (indians march on parliament over Aids drug patent, by Andrew Jack and Jo Johnson in New Delhi, May 10 2006).

The Indian oppositions directly concerned the global generic medicine market as Indian laboratories were supplying most ARVs consumed in the world. Cipla alone produced $40 \%$ of the ARVs used. This globalization of the generics market led to a globalization of solidarity and struggles between opponents. MSF South Africa, for instance, supported the Indian opponents: "We have all been waiting impatiently to get Tenofovir as a generic from India. It's clear that the world desperately needs more sources of Tenofovir. If Gilead is granted the patent, our patients will face a potentially deadly delay" (Eric Goermaere, MSF in South Africa, New York Times, 10 May 2006). In June 2008 this globalization of struggles against medicine patents resulted in the Brazilian HIV/Aids patient organization and the Indian organization SAHARA joining forces to file a new opposition at the Indian Patent Office, against a patent on Tenofovir: "However, this is the first time that a foreign patient group has countered an application in India. The case against Gilead's patent application will be filed formally by ABIA and the Centre for Residential Care \& Rehabilitation, an Indian NGO. The patent application has also previously been opposed by groups such as the Indian Network for People Living with HIVIAIDS" ("Brazil \& India are increasingly challenging prices by opposing patents", Healthcare Briefing and Forecasts, July $2^{\text {nd }}$ 2008). Opposition by a Brazilian organization in India was justified by the concern to safeguard the possibility for Brazil's Aids programme to import an Indian generic of Tenofovir. Whereas the Brazilian Patent Office had published a negative examination report on the Gilead patent in April 2008, the examination of the Indian patents was still underway at the time: "Though we are confident that patent will not be granted for Tenofovir in Brazil, we must ensure that the option of importing affordable generic versions from India remains open to our AIDS programme", commented Veriano Terto, ABIA's general coordinator. "This will contribute to the sustainability of our national AIDS programme's universal access policy, on which 180,000 Brazilians depend for their lives" (Business Standard, New Delhi, 27 June 2008). This 
globalization of oppositions bears witness to the existence of a South-South generics market, particularly between India and Brazil, and a solidarity between NGOs to preserve the existence of this market: "We want more options to promote competition in the market and bring down medicine prices", Gabriela Chavez, a pharmacist with ABIA, told The Hindu over the phone from Brazil. "If the patent is granted in Brazil but not in India, Brazil has the option to apply for a compulsory licence [a provision for public health emergencies sanctioned by the World Trade Organisation] to buy the medicine at lower cost from Indian companies. If the patent is not granted in Brazil or India, Brazil has the option to import either the key ingredients or the finished medicines from Indian companies," she said (The INDU, 27 June 2008). In so doing, the patient organizations that had recruited pharmaceutical and legal experts devised a sophisticated strategy to organize the generics market.

In the case of Tenofovir, the globalization of the struggles against medicine patents translated into multiple interactions and acts of solidarity between Brazil and India. First, oppositions were filed in parallel in both countries in 2006, and were defended by HIV/Aids patient organizations and generics producers: the federal FarManguinhos laboratory in Brazil and Cipla in India. Second, Brazilian and Indian NGOs and lawyers traded information. For example, the opposition drawn up by Wanise Barrosso at FarManguinhos was communicated to an Indian NGO via MSF. In 2009 an Indian lawyer from the NGO I-MAK thanked his Brazilian counterpart at ABIA: "Thanks to Francisco Neves da Silva of ABIA for pointing out that the application number of the Tenofovir application refused by INPI was ... " (20 July 2009). Third, in June 2008, a Brazilian and an Indian NGO filed a joint opposition in India. Fourth, in November 2008 the organization ABIA organized a seminar in Rio de Janeiro on the art and way of drawing up and filing oppositions, to which I-MAK, the NGO of alternative Indian lawyers, contributed. The head of intellectual property at I-MAK titled his talk: "Making the patent system more democratic: the role of public participation". This seminar reviewed pharmaceutical patents and the flexibilities in the law that the NGOs could use to defend the interests of patents and public health. Participants included Eloan Pinheiro, who in 1997 had launched the public programme to copy generic ARVs at the federal laboratory FarManguinhos, Carlos 
Correa, author of a report for the WHO on the flexibilities in pharmaceutical patents ${ }^{34}$, the lawyers of Brazilian and Indian NGOs, and Wanise Barroso from FarManguinhos. Fifth, in 2009 the Brazilian and Indian patent offices both refused Gilead's patents on Tenofovir, on the basis of the lack of novelty and inventive activity of the patent in Brazil, and Article $3 d$ of the Indian law that proscribed the patenting of new pharmaceutical forms of a known substance without new therapeutic utility. These parallel decisions opened the space for copying in Brazil and India, and for the generics market between the two countries. In Brazil, the public and private pharmaceutical laboratories worked together to produce a Brazilian Tenofovir.

\section{5- Public interest and medicine patents: jurisprudence in the Glivec case in India (2006-2009)}

In January 2006 the Indian Patent Office refused the patent application filed by Novartis for Glivec, a cancer medicine used to treat leukaemia. This refusal was the outcome of an opposition filed by the Cancer Patient Aid Association and several generics firms, including Cipla. The opponents' demand for a refusal of the patent, based on Article $3 \mathrm{~d}$ of the Indian patent law, was validated by the patent office on the grounds that Novartis' patent application was for a new pharmaceutical form of a known substance and that it was therefore not patentable in India ${ }^{35}$. This decision was the first to be taken under the new patent law of March 2005. Its implications were crucial for setting the standards of medicine patentability in a country as strategic as India in the generics economy. Novartis grasped the opportunity to kill two birds with one stone. In May 2006 it appealed against the decision on Glivec, and simultaneously challenged the constitutionality of Article $3 \mathrm{~d}$ and its conformity with the TRIPS agreements. The outcome of the conflict would have a direct impact on the production and availability of Glivec generics (several Indian laboratories supplied a generic at a price ten times lower than the patented medicine). It would also delimit the room to manoeuvre that states would have in applying the WTO agreements on

\footnotetext{
${ }^{34}$ Correa Carlos, 2007, "Guidelines for the examination of pharmaceutical patents: developing a public health perspective", ICTSD, WHO, UNCTAD.

${ }^{35}$ Decision of 25 January 2006, V. Rengasamy, Asst. Controller of Patents \& Designs.
} 
intellectual property rights on medicines ${ }^{36}$. In parallel with its lawsuit, Novartis highlighted the free distribution of Glivec that it had set up in India and that concerned 11,000 patients $^{37}$ - to which the opponents replied that India recorded 25,000 cases of Chronic Myelloid Leucemia annually.

The legal tug-of-war took place against a background of international public controversy. Patient organizations and international NGOs like MSF and Oxfam engaged in campaigns for access to treatment emphasized the impact of this trial on the global economy of copying and generic production: "If Novartis wins the Glivec trial and manages to change Indian law, India will have to agree to patents that are as broad and numerous as in the rich countries. This means that Indian generics producers will no longer be able to produce as many generics of patented products as in the other countries for the 20 years of the patent's life, and there will be fewer or no essential medicines at low prices available to poor countries" (MSF, 20 December 2006). That was also the Indian patient organizations' position: "This affair is particularly important, as it is the first trial concerning patents. Novartis is busy challenging the legal validity of all the patents refused, not only that of Gleevec. If Novartis wins this case, the price of several medicines will shoot up, not only that of Gleevec", commented M. Park, the lawyer of a cancer organization ${ }^{38}$. The HIV/Aids patient organizations joined forces with their cancer patient counterparts, and the Indian Communist Party, a member of the governing coalition at the time, published a communique that sounded the alarm on predictable ARV price increases ${ }^{39}$.

In August 2007, to the great satisfaction of generics producers and NGOs, the Chennai court ruled that Article $3 \mathrm{~d}$ of the Indian patent law was not unconstitutional, and dismissed Novartis' case. The court's justifications for this decision shed light on what I see as two essential issues: the making of medicine patents by the patent office examiners; and the public interest that lies in balancing ownership of medicine patents. As regards the first point the examination of patents, Novartis claimed that

\footnotetext{
${ }^{36}$ This aspect of the process is similar to that in the Pretoria case concerning the legal validity of two articles of the South African medicine law.

${ }^{37}$ On this subject, see the article by Stefan Ecks, 2008, "Global pharmaceutical markets and corporate citizenship: the case of Novartis' anti-cancer medicine Glivec", Biosocieties 3(2008), 165-181.

38 "La production indienne de médicaments génériques en danger", Essentialmedicines.access, 16 March 2007.

${ }^{39}$ Essentialmedicines.access, op.cit.
} 
Article $3 \mathrm{~d}$ of the Indian patent law, on the evaluation of the novelty of an invention, was vague and arbitrary. In particular, it argued that Section $3 \mathrm{~d}$ contained no guidelines to help examiners in deciding whether an invention was patentable. The court replied that the Patent Office examiners were fully competent to judge the novelty and gains in efficacy of the patented substance, on the basis of the patent documentation, and that the applicant had complete latitude to demonstrate the gains in therapeutic efficacy with the new substance. The Chennai court highlighted the concrete interpretative and assessment work of the patent examiners. Concerning the second point, it based the constitutionality of Article $3 \mathrm{~d}$ of the patent law on the public interest. The judges considered that the objective of this article was to prevent the evergreening of medicine patents and, in so doing, to fulfil the constitutional obligation to provide the country's citizens with good healthcare: "We have borne in mind the object which the amending Act wanted to achieve, namely, to prevent evergreening; to provide easy access to the citizens of the country to life saving medicines and to discharge its constitutional obligation of providing good health care to its citizens" 40 . The public health interest can thus legitimately be mobilized by a state to make and amend medicine patent laws.

In August 2007 the Chennai High Court confirmed the legitimacy of the Indian patent law, and in June 2009 the Intellectual Property Appellate Board (IPAB) upheld the decision to refuse Novartis' patent on Glivec: "The IPAB held that Novartis was not entitled to a patent on imatinib mesylate as its claimed product did not meet the requirement of increased therapeutic efficacy" (Lawyers Collective, 28 August, New Delhi). The Intellectual Property Appellate Board extended the reasons for its refusal to the excessively high price of Glivec commercialized by Novartis, which it said was disruptive to public order: "Thus, we also observe that a grant of product patent on this application can create havoc to the lives of poor people and their families affected with the cancer for which this medicine is effective. This will have a disastrous effect on society as well. Considering all the circumstances of the appeals before us, we observe that the Appellant's alleged invention won't be worthy of a reward of any product patent on the basis of its impugned application for not only for not satisfying the requirement of Section $3(\mathrm{~d})$ of the Act, but also for its possible

\footnotetext{
${ }^{40}$ In the High Court of Judicature at Madras, 6 August 2007, Novartis vs Union of India, The Controller General of Patents\&designs, Natco Pharma, Cipla, Hetro Medicines, Cancer Aid Association, Ranbaxy, Indian Pharmaceutical Alliance, Sun Pharmaceutical Industries.
} 
disastrous consequences on such grant as stated above, which also is being attracted by the provisions of Section 3(b) of the Act which prohibits grant of patent on inventions, exploitation of which could create public disorder among other things"41. This new argument had never been heard before in a patent Appeal Court. The European Patent Office, for example, had always refused to take into consideration the impact of patents on the price and accessibility of treatments: "It is not the EPO's duty to take into consideration the economic effects of issuing patents in certain specific areas"42. Certain opponents naturally deplored this stance of the EPO. In August 2009 Novartis decided to lodge an appeal with the Indian Supreme Court against this new refusal.

In the meantime, the Indian patent office had refused a second Novartis patent on another form of Glivec - an alfa rather than a beta crystal - which had also been opposed by three Indian firms. This new decision, in April 2009, was taken on the same grounds as the first one: "if granted, it would have been a clear case of frivolous patenting. This different form of Glivec is in no way superior to the other form for which a patent has not been granted", said an attorney involved in the opposition" (essentialdrugs.org, 3 june 2009). The cancer patient organizations and generics laboratories played an essential part in producing this jurisprudence.

\section{6- New players in the intellectual property field and practical alternatives to patent rights}

The growing conflict around medicine patents in Brazil and India in the 2000s was characterized by the opening of the circle of players to organizations in civil society, Ministries of Health, and generics laboratories. A process of democratization of intellectual property rights was thus witnessed, through campaigns for compulsory licences and the oppositions that were launched from 2005 by patient organizations. We also observed a phenomenon of legal acculturation of these civil society organizations, which incorporated legal experts into their teams or obtained assistance from alternative legal organizations. Alternative practices in patent law

\footnotetext{
${ }^{41}$ IPAB, ORDER (No.100/2009).

${ }^{42}$ EPO communiqué of 17 January 2005, on oppositions against Myriad Genetics' European patents on genes and on genetic tests for breast cancer predisposition.
} 
thus emerged, to defend the interests of patients and of public health, based on a conception of intellectual property that emphasizes its social function.

Until 2001, HIV/Aids patient organizations in Brazil focused their action on assisting patients and on prevention. They moved into the intellectual property field during the two battles of 2001: first, the Pretoria trial at the beginning of the year, which was marked by an intense globalization of conflicts over medicine patents; and, second, the complaint filed by the United States at the WTO against an article in Brazilian IP law, on compulsory licences (Shanker 2001; Varella 2002). In December 2002 a coordinator of one of the largest Brazilian HIV/Aids patient organizations described this shift: "The first meeting was organized at the same time as the alliance of pharmaceutical industries that were busy suing the South African government. We demonstrated outside the US consulate in Rio and Sao Paulo, outside the embassy in Brasilia, and outside the consulate in Recife. There was a meeting with all the organizations working on Aids in Recife, last year. This meeting was a way of mobilizing the groups to say that we needed a permanent and regular space for discussions on the subject of intellectual property ... In 2002 we organized three meetings between the organizations working in different areas, to discuss intellectual property" (Carlos Pasarelli, ABIA). The Brazilian Ministry of Health encouraged the Aids organizations to intervene with regard to intellectual property and access to treatment: "the government complained: it considered that NGOs in Brazil don't work on this subject of intellectual property" (Carlos Pasarelli). In 2001 the Ministry of Health engaged in a struggle with the multinationals over the price of ARVs, and threatened them with compulsory licences. It needed the support of civil society. Moreover, Minister of Health José Serra had decided to run for president in the upcoming elections, and part of his campaign was on the policy of access to generic medicines and on clashes over compulsory licences with the multinationals and with the US government. The Minister of Health thus participated in the organization of civil society. MSF Brazil also contributed strongly to the acculturation of Aids NGOs on medicine patents: "I've been fighting for a year now because the Brazilian nonprofit organizations aren't used to doing so ... for three years a colleague said to me: Michel, you're boring me with your stories of patents. We're pushing the government to give us medicines, it's up to the government to meet its responsibilities, if there's a need to 'quash patents', as we say, then it's up to it to do so" (M. Lostrowska, December 2002). MSF endeavoured to educate people with regard to compulsory 
licences: "I can tell you that, in my budget next year, I've provided for an international seminar in Rio on the compulsory licence, and we're going to make a noise. I'm going to get the world's leading specialists to come over, ... We're going to invite the Minister of Health, and the INPI, and we're going to say: here's the recipe for issuing a compulsory licence" (M. Lostrowska, December 2002). Acculturation in intellectual property rights is remarkable in ABIA's trajectory since 2002. In 2006 the organization recruited a lawyer to take over the file, and he drew up the oppositions filed by $A B I A$ in the same year. In November 2008 ABIA organized a course on how to go about opposing patents, with the participation of international experts (Carlos Correa) and an NGO of alternative Indian lawyers, I-MAK. The learning process underway was also evidenced in the organization's publications: until 2001 the journal published by ABIA contained no references to patents. In 2009 its website featured reports, publications and the outcome of the oppositions to the medicine patents that it had engaged. That year the lawyers of the HIV/Aids organizations published a synthesis article on civil society's action on intellectual property (Chavez, Viera \& Reis) ${ }^{43}$.

We also find a phenomenon of symmetrical acculturation at the FarManguinhos federal laboratory, which set up an intellectual property and technology transfer unit in the late 1990s. It recruited two experienced patent examiners from the INPI and a young chemist who had training in conflict over compulsory licences. The new IP unit prepared arguments on compulsory licences, filed oppositions in 2006, and patented new molecules developed through local research. The Ministry of Health also developed expertise in intellectual property, through the experts at FarManguinhos, reports from independent consultants (e.g. the report on the preparation of compulsory licences drawn up in 2004 by a patent expert), interaction with MSF's campaign for access to essential medicines, and the seminars on IP law and economics that it had organized regularly since 2002. It was the Ministry that prepared the file for the Efavirenz compulsory licence in 2007 (Possas 2008). There is of course also a circulation of knowledge between the NGOs, FarManguinhos and the Ministry of Health on the subject of patents, oppositions, compulsory licences, and local production of generics. Two NGOs, MSF and $A B I A$ financed expertise by two university chemists on the Brazilian generics

\footnotetext{
43 "Access to medicines and intellectual property in Brazil: reflections and strategies of civil society", Sur- Revista International de Direito Humanos, vol. 5, $n^{\circ}$ 8, Sao Paulo, June 2008. See also "IPR and Access to ARV Medicines. Civil Society Resistance in the Global South", ABIA 2009.
} 
laboratories' technological capacities, which was subsequently used in the 2007 decision on a compulsory licence for importing and locally producing Efavirenz. From 2000 the NGOs have had a working group on intellectual property on a federal scale, in the REBRIP.

There is a network of lawyers in Brazil today, specialized in patents and based in Aids NGOs, at MSF, in the FarManguinhos federal laboratory and in the IP unit at ANVISA. They are all working together towards a better balance between patents and the public interest. Above all, they endeavour to use flexibilities in the WTO agreements on intellectual property, to support local production of generics or to invent ways to support pharmaceutical innovation oriented towards neglected diseases ${ }^{44}$. In India, patient organizations rely on the support of groups of alternative lawyers such as the Lawyers Collective HIV/Aids Unit, the Alternative Law Forum, and the organization I-MAK (Initiative for medicines access and knowledge) which drafted the oppositions to the Tenofovir patents. These lawyers use their expertise in intellectual property to dissolve monopolies and work towards a policy of access to treatment. They describe themselves as lawyers who practise law in an alternative manner, to destroy monopolies rather than creating them, or as public interest lawyers (Tahir Amin, lawyer with the alternative Law Forum in Bangalore). I-MAK presents itself as follows: "The Initiative for Medicines, Access \& Knowledge is a notfor-profit public service organisation consisting of lawyers and scientists working to protect the public domain against undeserved patents. I-MAK works to ensure that patents do not act as a barrier to research and restrict the public's access to affordable medicines". In November 2008 the I-MAK coordinator gave a lecture in Rio de Janeiro entitled: "Making the patent system more democratic: the role of public participation". It sought to define a method for filing oppositions ("How to oppose a patent?): collect expert assessments from lawyers, chemists and pharmacists; choose the right medicine to oppose, from the list of essential medicines; identify the right patents and check with a chemist which patent is actually used in the industry; obtain examination reports from the European and US patent offices' databases; and, finally, involve patient groups.

\footnotetext{
${ }^{44}$ From 2002 to 2006 MSF and FarManguinhos participated in the FACT consortium to invent new combinations of molecules to fight malaria. Cf. interview with M. Lostrowska, MSF Rio de Janeiro, December 2002.
} 


\section{Conclusion}

The various legal trials and conflicts that we have examined in this article have been instrumental in producing a new regulation of intellectual property with regard to medicines, in which countries of the global South and primarily Brazil and India are major players. The trials, oppositions, specific units for examining medicine patents, and campaigns for compulsory licences have all aimed to exploit and extend the flexibilities in patent law in a way that facilitates the copying of generic medicines and the accessibility of treatments. These struggles through and over the law have intensified since the early 2000s, especially since March 2005, when India adopted patents on pharmaceutical products. This is clearly a case of law in-the-making: within the group of examiners at the Brazilian medicine agency; in the IP unit at the FarManguinhos federal laboratory where a patent expert works to invalidate the pharmaceutical patent holders' arguments; and in the legal organization Initiative for Medicine Access \& Knowledge which prepares oppositions. It is also a case, in particular, of patent law in-the-making during legal battles such as lawsuits, oppositions filed with patent offices, and the preparation of compulsory licence decrees by Health Ministries. Social movements are mobilized, and when necessary they participate in these legal actions, filing oppositions with the patent office or as litigants in a trial. For instance, civil society organizations demonstrated outside the Indian parliament to support opposition against patents on Tenofovir, and participated in public debates on compulsory licences. In 2005 they intervened alongside the Ministry of Health. Law in-the-making is not isolated from socioeconomic struggles. It extends, codifies and organizes them. This may provide an answer to the question posed by Latour in La Fabrique du Droit (2002): "How can power relations be shifted in the law? Where are the vehicles? What are the channels?". The victorious oppositions of Brazilian and Indian NGOs against the patents of the US firm Gilead, over Tenofovir, redefined the relations of ownership of this ARV and the organization of its market. Brazilian and Indian laboratories were consequently authorized to freely copy and produce inexpensive generics. "Law informs economics", noted Michel Foucault (2004), and this has applied here via the struggles for the right to health, including the patient work of the ANVISA examiners and FarManguinhos patent experts who make patent law by mobilizing it and translating it into singular legal acts: examination reports, opposition reports, 
compulsory licence decisions. The patent examiners' interpretative work has led to court cases when the international pharmaceutical laboratories have rebelled against the refusal of major patents, e.g. ANVISA's refusal of Aventis' patent on Taxotere, and the Indian patent office's refusal of Novartis' patent on Glivec. Aventis sued ANVISA, while Novartis sued the Indian government. These clashes revealed the plurality of possible interpretations of patent law when Brazilian and Indian examiners raise the patentability standards to protect the public domain. Here the flexibilities in patent law stem from the interpretation of the rules of novelty and inventive activity, and in particular articles of national laws.

Government or citizen regulation has taken place during the process of examination and granting of property rights, via the oppositions filed by NGOs as "interested third parties", and via the prior consent system involving the Brazilian sanitary security agency in the medicine patenting process. In the latter case, the state, especially the Ministry of Health, altered the patenting procedure by granting the sanitary security agency the power to veto patents. The interests of public health were thus embedded in the IP decision-making process. Citizen regulation, on the other hand, appeared mainly through the opposition procedures filed with the patent offices, when these procedures were opened to the "interested parties". In pre-grant oppositions in Brazil and India, patient organizations or consumer unions moved in to participate in the patent examination process. These struggles through the law have involved a legal formatting of arguments by the specialized lawyers who assist the NGOs. The oppositions and public campaigns have structured the field of the forces of this new pharmaceutical economy: they have triggered the creation of consortiums of NGOs, and have often mobilized patient organizations, generics laboratories and Health Ministries. This triad of actors - civil society, Health Ministries, generics laboratories - have shaped a new pharmaceutical economy involving trade between countries and laboratories in the global South. At the same time, there has been complementarity between civil society and the state during these different actions to promote a biopolicy of access to medicines, promoted by generics producers in both the public sector (FarManguinhos) and the private sector (Cipla).

These oppositions and regulatory measures have tended to change the nature of intellectual property law, which now has to compromise with the public interest, patients' interests, and a universal right to health. The head of ANVISA's intellectual property unit mobilizes the "social function of property" category enshrined in Brazil's 
constitution, to balance patent-owner's interests. Likewise, the oppositions filed by Brazilian and Indian patient organizations were based on the "essential medicines" category to limit the extension of patent rights. The notion of essential medicines encompasses both their therapeutic use value and a norm of availability for patients. The Rio de Janeiro Federal Court referred to the public interest of patients when it authorized reverse engineering on patented medicines. The assertion of the public interest in the face of intellectual property rights was also the basis of the Chennai court's decision when Novartis challenged the constitutional nature of Indian patent law. Even the WTO incorporated the notion of the interests of public health into certain articles of the 1994 agreements on intellectual property, particularly the Doha Declaration of November 2001 which was adopted under pressure from Brazil and India. Brazil's Ministry of Health and NGOs advocating access to medicines used these initial successes concerning Efavirenz, Tenofovir, Glivec and Combivir, to explore more general ways in which accessibility of treatments could be guaranteed. Current reflection is oriented towards the collective management of property in patent pools managed by the United Nations, which would distribute non-exclusive licences to manufacturers, and towards automatic compulsory licence measures encompassing an entire therapeutic category to combat an epidemic ${ }^{45}$. Another option is to use new mechanisms for pharmaceutical innovation, especially in public/private partnerships formed deliberately outside of the patent sphere, like the FACT international consortium to fight malaria.

\footnotetext{
${ }^{45} \mathrm{Cf}$. the talk delivered by Eloan Pinheiro, former Director of FarManguinhos, at the conference on access to treatment, organized by the Ministry of Health, in May 2009 in Rio de Janeiro.
} 


\section{Bibliography}

ABIA (2009) «IPR and Access to ARV Medicines. Civil Society Resistance in the Global South », report, 135 pages.

Barroso W (2009) «Le cas du Tenofovir », communication au $5^{\text {ème }}$ Congrès VIH/sida de Casablanca, mars 2010.

Basso M (2006) « Intervention of health authorities in patent examination: the Brazilian pratice of the prior consent », Int. J. Intellectual Property Management Vol. $1, n^{\circ} 1 / 2,54-74$.

Beigbeder Yves (2004), International public health: patients' rights vs. patent rights, Ashgate.

Biehl J (2009) "Accès au traitement du sida, marchés des médicaments et citoyenneté dans le Brésil d'aujourd'hui », Sciences Sociales et Santé, ", Sciences Sociales et santé, $n^{\circ} 3$, vol $27,13-46$.

Cassier M (2000) "Genome Patents Nowadays and Pharmaceutical Patents in the 19th: a parallel", International Conference, "Technological Policy and Innovation: Economic and historical perspectives", Paris, 20-22 November, 22 pages.

Cassier M (2002) «Propriété intellectuelle et santé publique », Revue Projet, mai, p 47-55.

Cassier M, Correa M (2003) «Patents, Innovation and Public Health: Brazilian Public-Sector Laboratories' experience in copying AIDS medicines", in Economics of AIDS and Access to HIVIAIDS Care in Developing Countries. Issues and Challenge, Ed. ANRS, p 89-107.

Cassier M, Stoppa Lyonnet D (2005) L'opposition contre les brevets de Myriad Genetics et leur révocation totale ou partielle en Europe » - Opposition to Myriad Genetics patents and their total or partial revocation in Europe: early conclusions, Médecine/Sciences, $\mathrm{n}^{\circ}$ 6-7, vol 21, June-July 2005, p 658-662.

Chaves G, Viera M, Reis R (2008) « Access to medicines and intellectual property in Brazil : reflections and strategies of civil society », Sur.Revista Internatcional de Direitos Humanos, vol.5, ${ }^{\circ} 8$, June.

Cohen J C (2000) " Public Choices in the Pharmaceutical Sector: a Case Study of Brazil ». LCHSD Paper Series $n^{\circ}$ 54, Human development Department, The World Bank.

Commission on Intellectual Property Rights - CIPR- (2002) Integrating Property Rights and Development Policy, 178 pages. 
Correa Carlos (2007) Guidelines for the examination of pharmaceutical patents: developing a public health perspective. ICTSD, WHO, UNCTAD, 2007.

D'Almeida C, et al (2008) "New antiretroviral treatments and post-2005 TRIPS constraints : first moves towards IP flexibilization in developing countries" in The Political Economy of HIV/AIDS in Developing Countries, Ed by B. Coriat, Edward Elgar, London, 25-51.

Ecks Stefan (2008) «Global Pharmaceutical markets and corporate citizenship: the Case of Novartis' anti-cancer medicine Glivec, Biosocieties 3, 165-181.

Foucault M (2004) Naissance de la biopolitique, Cours au collège de France (19781979), Seuil.

Flynn M, 2007, « Brazil's Use of Compulsory Licenses for AIDS medicines », American Sociological Association, August 1-4, 1-20.

Flynn M, De Oliviera E A (2009) « Regulatory Capitalism in Emerging Markets: an Institutional Analysis of Brazil's Health Surveillance Agency (ANVISA), American Sociological Association, august 8-11, San Francisco, 1-20.

Galvao J. (2002) Access to antiretroviral medicines in Brazil, The Lancet, volume 360 , Issue 9348, 1862-1865.

Guimaraes E (2008) "Le droit à la santé et la propriété intellectuelle des médicaments au Brésil : I'examen préalable à l'Agence de Surveillance Sanitaire » mémoire de Mestrado, Institut de Médecine Sociale, UERJ.

Harhoff D (2000) «Determinants of opposition against EPO patent grants. The case of biotechnology and pharmaceuticals », collection Les Cahiers de l'innovation, CNRS, $27 \mathrm{p}$.

Lanjouwe J.O. (1997) The introduction of pharmaceutical products patents in India: heartless exploitation of the poor and suffering ?", Yale University, 54 pages.

Latour B (2002) La Fabrique du droit, La Découverte.

Loyola MA. (2009) « Sida, santé publique et politique du médicament au Brésil : autonomie ou dépendance », Sciences Sociales et santé, $n^{\circ}$ 3, vol 27, p 47-75.

National Academy of Science (1997) « America's vital interest in global Health: protecting our people, enhancing our economy and advancing our international interest », Board on International Health, Institute of Medicine, NATIONAL 
ACADEMY PRESS, Washington, D.C.

May C (2000) A Global Political Economy of Intellectual Property Rights. The new enclosures? », Routledge.

Possas C (2008) « Compulsory Licensing in the real world: the case of ARV medicines in Brazil », in The Political Economy of HIVIAIDS in Developing Countries, Ed by B. Coriat, Edward Elgar, London, 150-166.

Sahu S (1998) Technology transfer, dependence, and self-reliant development in the third world, Praeger, London, $250 \mathrm{p}$.

Shanker D. (2001) « Brazil, Pharmaceutical Industry and WTO » University of Wollongong, New South Wales, Australia.

Scherer F (2000) "Le système des brevets et l'innovation dans le domaine pharmaceutique », Revue Internationale de Droit Economique, $\mathrm{n}^{\circ} 1$.

Scherer F and Watal J (2001) « Post Trips Options for Access to Patented Medicines in Developing Countries ", Commission on Macroeconomics and Health, WHO, 2001, 77 pages.

Shelden K (2009) « The Political Contradictions of Incremental Innovation in Late Development: Lessons from Pharmaceutical Patent Examination In Brazil », 1-29.

Tahir Amin (2008) "Making the patent system more democratic: The role or Public Participation », Examination of Pharmaceutical Patents: Arguing from a Pro-Public Health Perspective, Associacao Brasileira Interdisciplinar de AIDS - ABIA Rio de Janeiro, 18 November.

Teixeira P, Vitoria MC, Barcarolo (2003) The Brazilian experience in providing universal access to antiretroviral therapy, In: Moatti J.-P., Coriat B., Souteyrand Y., Barnett T., Dumoulin J., Flori Y.-A., eds, Economics of AIDS and access to HIVIAIDS. Issues and Challenge, Ed. ANRS,

Varella M ( 2002) La propriété intellectuelle des produits pharmaceutiques au Brésil, 66 pages.

Velasquez G, Correa C, Thirukumaran Balasubramaniam (2004) «WHO in the Frontlines of the Access to Medicines Battle: The Debate on Intellectual Property Rights and Public Health », Intellectual Property in the context of the WTO TRIPS Agreement », Eds J. Bermudez, MA Oliviera, Fiocruz, 83- 97.

Villela Pedro (2009) « Activistes du VIH/SIDA et l'économie politique du médicament » Master's thesis, EHESS, Paris. 